\title{
Genetics of $\beta$-Amyloid Precursor Protein in Alzheimer's Disease
}

\author{
Julia TCW and Alison M. Goate \\ Department of Neuroscience, Icahn School of Medicine at Mount Sinai, New York, New York 10029 \\ Correspondence: julia.tcw@mssm.edu; alison.goate@mssm.edu
}

\begin{abstract}
Alzheimer's disease (AD) is characterized neuropathologically by neuronal cell loss, extracellular neuritic plaques composed of $\beta$-amyloid $(A \beta)$, and intracellular neurofibrillary tangles composed of hyperphosphorylated tau protein. $A \beta$ is generated by proteolytic processing of the $\beta$-amyloid precursor protein (APP). Most individuals with Down syndrome (DS) have three copies of APP, leading to elevated APP expression, increased A $\beta$ deposition, and characteristic $\mathrm{AD}$ neuropathology. Sequencing of $A P P$ in familial early-onset $\mathrm{AD}$ identified missense mutations that cause $A D$, while a recently discovered coding variant, APP A673T, reduces the risk for AD. Cellular and animal studies show that risk-associated mutations increase total $A \beta$ levels, $A \beta 42$ levels, or $A \beta$ fibrillogenesis, while protective alleles reduce $A \beta$ levels. Together, these studies provide compelling evidence for the $A \beta$ hypothesis and suggest that therapeutics that reduces $A \beta$ levels or $A \beta$ fibrillogenesis should lower the risk for or prevent AD.
\end{abstract}

\begin{abstract}
lzheimer's disease (AD) exists as two genetAically distinct forms: familial AD (fAD), which is usually characterized by the clinical onset before 60 years of age and Mendelian inheritance, and late-onset or sporadic $\mathrm{AD}(\mathrm{sAD})$ (Sadowski et al. 1999), which usually has a clinical onset after 60 years of age and exhibits no consistent pattern of inheritance (Bertram and Tanzi 2005). Early-onset fAD, which represents $<1 \%$ of $\mathrm{AD}$ cases, is caused by rare and fully penetrant mutations in three different genes encoding $\beta$-amyloid precursor protein (APP) on chromosome 21, presenilin-1 (PSEN1) on chromosome 14, and presenilin-2 (PSEN2) on chromosome 1. (For additional details on the presenilin complexes, see Johnson et al. 2016.) In contrast, the most common form of the disease,
\end{abstract}

late-onset or $\mathrm{sAD}$, probably reflects the cumulative effects of both common and rare genetic risk factors and the environment. The $\varepsilon 4$ allele of the apolipoprotein E (APOE) gene is the most common risk factor for $\mathrm{AD}$ and is associated with a dose-dependent increase in the risk of developing late-onset $\mathrm{AD}$ (a threefold increase for one copy of APOE4 and a 10-fold increase for two copies of APOE4) and decrease in age at onset.

The human APP gene was first identified in 1987 using partial protein sequence information from purified $\beta$-amyloid $(A \beta)$ to identify the corresponding cDNA (Kang et al. 1987). The gene was mapped to chromosome 21 (21q21.2-3) (Goldgaber et al. 1987; Tanzi et al. 1987). APP is a type I membrane protein with a large extracellular domain and a short cytoplas-

Editor: Stanley B. Prusiner

Additional Perspectives on Prion Diseases available at www.perspectivesinmedicine.org

Copyright (C) 2017 Cold Spring Harbor Laboratory Press; all rights reserved; doi: 10.1101/cshperspect.a024539

Cite this article as Cold Spring Harb Perspect Med 2017;7:a024539 
J. TCW and A.M. Goate

A

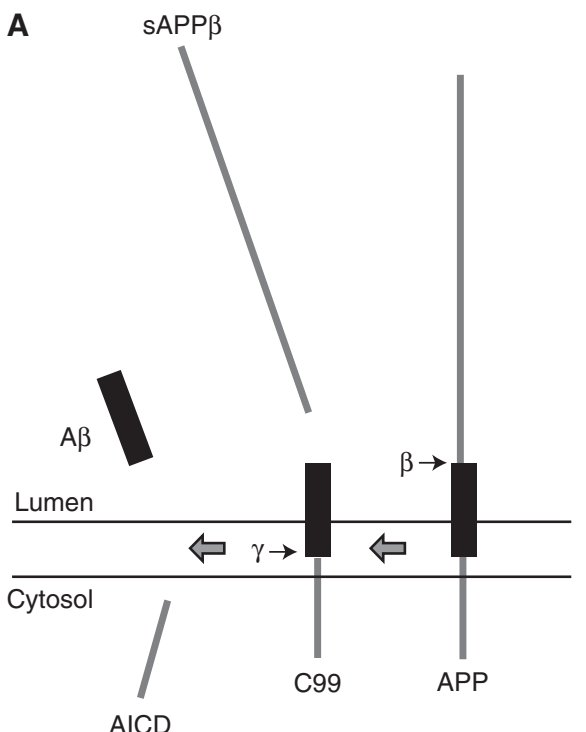

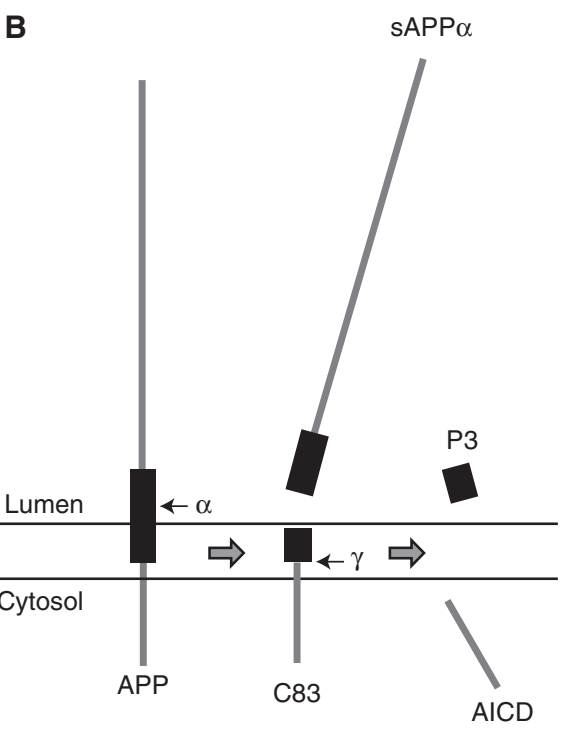

Figure 1. Processing of $\beta$-amyloid precursor protein (APP) by the secretases: $(A)$ amyloidogenic processing and (B) nonamyloidogenic processing.

mic region. Two cleavage events, one in the extracellular domain ( $\beta$-secretase cleavage) and one in the transmembrane region $(\gamma$-secretase cleavage), are necessary to release A $\beta$ from APP (Fig. 1A). Several different APP proteins can be derived by alternative splicing from this single gene (695-770 amino acids). The major splice form in neurons is APP695 (Sandbrink et al. 1996).

The precursor proteins are proteolytically cleaved by two distinct pathways. In the nonamyloidogenic processing pathway, APP is cleaved within the $A \beta$ domain by $\alpha$-secretase, with the formation of a large soluble ectodomain $(\mathrm{sAPP} \alpha)$ and an 83-residue membraneassociated C-terminal fragment (C83) (Fig. 1B). Several members of the ADAM family of proteases have $\alpha$-secretase activity. Subsequent cleavage of $\mathrm{C} 83$ by $\gamma$-secretase leads to the formation of $\mathrm{P} 3$ and the APP intracellular domain (AICD) (Fig. 1B). In the amyloidogenic pathway, APP is cleaved at the N-terminus of the A $\beta$ domain by $\beta$-secretase or BACE, a membranetethered protease, resulting in the generation of a soluble ectodomain ( due, membrane-retained C-terminal fragment
(C99) (Fig. 1A). Subsequently, $\gamma$-secretase, a membrane-embedded complex with presenilin as the catalytic component, cleaves C99 to release $\mathrm{A} \beta$ peptides and AICD (Fig. 1A) (Haass 2004). Because the site of $\gamma$-secretase cleavage is promiscuous, it generates $A \beta$ peptides with different $C$ termini, including $A \beta 1-40(A \beta 40)$, $A \beta 1-42$ (A $\beta 42)$, and other minor species (Ling et al. 2003; Kaminsky et al. 2010). Under normal physiological conditions, $A \beta 40$ is the most abundant species generated in the amyloidogenic pathway, with $A \beta 42$ representing only $10 \%$ of total $A \beta$ (Wiltfang et al. 2002). However, $A \beta 42$ is considered the harmful peptide because it is more prone to fibril formation and promotes $A \beta$ aggregates, which are the key effectors of neurotoxicity (Wolfe and Guenette 2007; see also Prusiner 2016; Tycko 2016).

Although mutations in the APP gene explain only a small proportion of $A D$ cases, these mutations, including duplication of $A P P$ and missense mutations, directly implicate $A \beta$ generation as a causal factor in $\mathrm{AD}$ pathology. The mechanistic link between $\mathrm{AD}$ and $A P P$ has been further strengthened by studying Down syndrome (DS). 


\section{DOWN SYNDROME: TRISOMY OF CHROMOSOME 21}

DS is the most common human aneuploidy, caused by trisomy of all or part of human chromosome 21 (HSA21) (Patterson 2009). This additional genetic material alters brain development and causes lifelong intellectual disability. Interestingly, AD pathology occurs at a high frequency in DS patients and progresses in an age-dependent manner. All individuals with DS caused by complete trisomy of HSA21 develop a neuropathology indistinguishable from $\mathrm{AD}$ by the age of 30-40 years (Burger and Vogel 1973; Oyama et al. 1994), and 67\% develop an AD-type dementia by the age of 72 (Wisniewski et al. 1985; Mann and Esiri 1989; Zigman 2013). Multiple brain regions in individuals with DS undergo significant atrophy and loss of neurons with increasing age. The brains of older adults with DS show more than $40 \%$ of total volume loss and a $90 \%$ reduction in neuronal density in the entorhinal cortex. Additionally, like individuals with $\mathrm{AD}$, individuals with DS display an age-dependent $A \beta$ deposition, progression of neuroinflammation, neurofibrillary tangles, hyperphosphorylation of the microtubule-associated protein tau, and degeneration of basal forebrain cholinergic neurons (Hof et al. 1995; Sadowski et al. 1999). A $\beta$ deposits begin to appear in individuals with DS as young as 10 years of age but are consistently found in the brains of DS individuals over 40 (Rumble et al. 1989). The abnormal accumulation of $A \beta$ in the brains of both $\mathrm{AD}$ and $\mathrm{DS}$ patients induces cognitive decline through neural dysfunction. Because the APP gene is located on HSA21, it is present in three copies in DS individuals, leading to overexpression of APP and increased generation of $A \beta$. Even in the brains of fetuses with DS, the excess gene dosage of APP leads to early elevation of A $\beta$ levels (Teller et al. 1996). It has been hypothesized that the triplication of $A P P$ in DS leads to AD symptoms early in life through overexpression of APP (Rumble et al. 1989), followed by deposition of $A \beta$ and neurodegeneration (Wisniewski et al. 1985). Studies of DS, therefore, strongly support $A P P$ as a candidate causal gene in AD. However, a caveat to this is that many other genes are encoded by chromosome 21 and are overexpressed in DS (Hattori et al. 2000). Studies of the small percentage of DS cases that are caused by partial trisomy of HSA21 have helped to address this issue. Fine mapping in these individuals has shown that the so-called DS critical region (21q22.3), which is sufficient to produce the characteristic facies and developmental delay associated with DS, does not include the APP gene (Korenberg et al. 1990). However, AD neuropathology was not among the cardinal features considered for the DS phenotypes in this study. Other supportive evidence comes from the postmortem examination of a 78-yr-old woman with DS features because of a partial trisomy involving the distal 21q region. Despite her advanced age, she had no neuropathological evidence of $\mathrm{AD}$ (Prasher et al. 1998). Although a segment of HSA21 was triplicated, this region did not include the APP gene. Thus, the study of partial trisomies of HSA21 supports the hypothesis that triplication of $A P P$ is necessary for $\mathrm{AD}$ pathology in DS cases. These data also strongly suggest that $\mathrm{DS}$ and $\mathrm{AD}$ share pathogenic mechanisms and that the early onset of AD pathology in DS is in part a result of overexpression of the $A P P$ gene by gene-dosage imbalance (Salehi et al. 2006).

\section{APP LOCUS DUPLICATION FAMILIES}

Another feature of the mammalian genome that induces variation in gene expression is the presence of copy number variations (CNVs), which include both gene duplications and deletions. CNVs are regions of DNA, which can be variable in size, the copy number of which varies between individuals. Both common and rare de novo CNVs have been reported in the human genome (Zarrei et al. 2015). Much effort has been expended to identify and map CNVs in normal individuals and in disease (Henrichsen et al. 2009). Duplication of a region of HSA21 containing the APP gene has been reported to cause AD in several families with an autosomaldominant form of the disease (Rovelet-Lecrux et al. 2006; Sleegers et al. 2006). Genomic duplications of small regions of HSA21, including 
the APP locus, have been reported in nine families of different ethnic origins_-French, Dutch, Japanese, and Swedish (Rovelet-Lecrux et al. 2006; Sleegers et al. 2006; Guyant-Marechal et al. 2008; Kasuga et al. 2009; Thonberg et al. 2011). These families have different overlapping duplications that each includes the APP locus. None of the families exhibited any clinical features suggestive of DS, other than progressive dementia of the AD type. Neuropathological examination of these brains showed abundant $\mathrm{A} \beta$ deposits and neurofibrillary tangles in the parenchyma and the induction of $A \beta$-related cerebral amyloid angiopathy (CAA) in the cerebral vasculature (Ellis et al. 1996; Pfeifer et al. 2002; Guyant-Marechal et al. 2008).

To address how far the duplications extend into the flanking chromosomal regions and investigate whether any neighboring genes were duplicated in addition to $A P P$, copy-number assays targeting the genes around $A P P$ were analyzed in these families. Further fine mapping of the chromosomal region by array-comparative genome hybridization confirmed the presence of a genomic duplication of the APP gene and evaluated the size of the duplicated region. The measured size of duplicated segments, including the APP locus from five French families, ranged from 0.58 to $6.37 \mathrm{Mb}$ and contained from five to 12 annotated genes, centromeric to the DS critical region (Rahmani et al. 1989). Compared to the French families, the duplicated genomic region in early-onset $\mathrm{AD}$ Dutch patients was much smaller $(0.7 \mathrm{Mb})$ and included no other genes but APP (Sleegers et al. 2006). A real-time quantitative polymerase chain reaction of the $A P P$ promoter confirmed that the genomic duplication included APP and its promoter region but none of the adjacent genes. This suggests that a genomic duplication of $A P P$ is sufficient to cause the mixed phenotype of $\mathrm{AD}$ and CAA, without contribution from any of the adjacent genes. The size of the duplicated region in the Swedish cases was also small, $1.01-1.09 \mathrm{Mb}$, and included no flanking genes.

In the French families, a genomic duplication in the APP locus was observed in five out of 65 families (nearly 8\%) with early-onset AD (Rovelet-Lecrux et al. 2006). In the Dutch pop- ulation-based sample, APP duplications were detected at a frequency of one in $10(10 \%)$ of the early-onset AD cases (Sleegers et al. 2006). While in the Swedish sample, one in 22 individuals $(4.5 \%)$ diagnosed with clinical early-onset AD carried a duplication on HSA21, including the APP locus (Thonberg et al. 2011). Together with the data from partial trisomies of HSA21, these families provide compelling evidence that duplication of $A P P$, resulting in overexpression of APP and elevated A $\beta$ levels, is sufficient to cause $\mathrm{AD}$ pathology and CAA.

\section{MISSENSE MUTATIONS IN THE APP GENE AND ITS NEUROPATHOLOGICAL PROFILE}

Like the duplications in $A P P$, most missense variants in $A P P$ are associated with autosomaldominant inheritance of $\mathrm{AD}$, usually with complete penetrance by age 60 (www.molgen.ua .ac.be/ADMutations). An autosomal-recessive mutation at codon 673 of $A P P$ was recently discovered and reported to be associated with $\mathrm{AD}$ (Giaccone et al. 2010). The APP gene is encoded by 18 exons that are alternatively spliced to produce proteins ranging in size from 695 to 770 amino acids. The A $\beta$ peptide is encoded by parts of exons 16 and 17 (Yoshikai et al. 1990). To date, 26 pathogenic missense mutations have been reported within the APP gene (Table 1). These mutations are located within or immediately flanking the $A \beta$ sequence. $A \beta$ is generated from APP by the sequential cleavage of two enzymes, $\beta$-secretase and $\gamma$-secretase (Figs. $1 \mathrm{~A}$ and 2 ). We will discuss further the mechanisms by which these mutations act and display their neuropathological hallmarks.

Table 1. Number of pathogenic mutations in APP gene in each type and domain

\begin{tabular}{llc}
\hline Type & \multicolumn{1}{c}{ Domain } & $\begin{array}{c}\text { Number of } \\
\text { mutations }\end{array}$ \\
\hline APP duplication & Entire sequence & $26(50.0 \%)$ \\
APP missense & N terminal & $1(1.9 \%)$ \\
mutation & A $\beta$ sequence & $11(21.2 \%)$ \\
& C terminal & $14(26.9 \%)$ \\
Total & & 52 \\
\hline
\end{tabular}


Autosomal-Dominant Mutations in APP and Their Associated Neuropathological Profiles

Mutations in the N-Terminal A $\beta$ Domain and Their Effects on A $\beta$ Formation

A double mutation in exon 16 of APP at codons 670 and 671 (using the numbering associated with the longest transcript of APP, APP770) was identified in a Swedish fAD pedigree (Mullan et al. 1992). These mutations result in a lysineto-asparagine substitution at codon 670 and a methionine-to-leucine substitution at codon $671(\mathrm{~K} 670 \mathrm{~N} / \mathrm{M} 671 \mathrm{~L})$ in the APP protein (Fig. 2 ; Table 1). These mutations are located at the $\mathrm{N}$ terminus of $A \beta$ at the $\beta$-secretase cleavage site within the extracellular domain of APP. The K670N/M671L mutation appears to augment the production of total $A \beta$, resulting in higher levels of both $A \beta 40$ and $A \beta 42$ in vitro (Busciglio et al. 1993; Citron et al. 1994). In addition, a significant threefold increase in $A \beta$ release is detected in peripheral fibroblasts from individuals carrying the Swedish mutation.

\section{Mutations within the $A \beta$ Domain and Their Effects on $A \beta$ Formation}

Ten pathogenic mutations have been reported within the A $\beta$ sequence: D678N, E682K (Leuven mutation), A692G (Flemish mutation), E693Q (Dutch mutation, HCHWA-D), E693K (Italian mutation), E693G (Arctic mutation), E693del, D694N (Iowa mutation), L705V, and A713T (Fig. 2; Table 1). The first pathogenic mutation to be reported in the APP gene was APP E693Q, reported in a Dutch family with an inherited cerebral hemorrhage with amyloidosis (HCHWA-D) in which the amyloidosis is caused by $A \beta$ (Levy et al. 1990). In vitro analysis of the full-length $A \beta$ peptide or fragments containing the E693Q mutation has revealed that the mutated peptide aggregates and forms amyloid-like fibrils much faster than the wild-type (WT) A $\beta$ sequence (van Duinen et al. 1987; Wisniewski et al. 1991).

Mutations within the $A \beta$ domain can have complicated effects on APP processing, including impaired $\alpha$-secretase cleavage and increased hydrophobicity of secreted A $\beta$ species, thereby enhancing aggregation of $A \beta$ into amyloid fibrils (Wisniewski et al. 1991; Haass et al. 1994). For example, E693G enhances $A \beta$ protofibril formation (Nilsberth et al. 2001). In contrast to other fAD cases with predominantly $A \beta 42$ plaques in the brain, it has been shown that $\mathrm{AD}$ patients carrying the $\mathrm{A} 692 \mathrm{G}$ mutation predominantly deposit $A \beta 40$, particularly in the vascular walls (Hendriks et al. 1992). Mutations associated with elevated $\mathrm{A} \beta 40$ species are associated with significant CAA and hemorrhagic stroke.

\section{Mutations in the $C$-Terminal $A \beta$ Domain and Their Effects on $A \beta$ Formation}

The first mutation to be associated with fAD was V7171 in exon 17 of APP in a family of British origin with an age at onset in the mid50s (Goate et al. 1991). Since this report, many other families have been reported carrying this same mutation as well as several other mutations at the same amino acid (V717G, V717L, and V717F). Early-onset AD mutations close to the $\gamma$-secretase cleavage site within the transmembrane domain of APP are located at APP714-717 and near the $\varepsilon$-secretase cleavage site at APP723-724. Fourteen mutations have been reported in the $\mathrm{C}$-terminal $\mathrm{A} \beta$ domain, including T714l/A, V715M/A, V716V/T/F/ $\mathrm{M}$, and $\mathrm{V} 717 \mathrm{l} / \mathrm{G} / \mathrm{L} / \mathrm{F}$ at codons $714-717$, and L723P and K724N at codons 723-724 (Fig. 2; Table 1). These mutations influence the activity of their respective secretases, resulting in aberrant processing of APP. Indeed, these APP mutations near the C-terminal region of the $A \beta$ sequence lead to a selective increase in the production of longer $A \beta$ peptides, especially those ending at residue $42(\mathrm{~A} \beta 42)$, which is prone to more rapid aggregation (Hardy 1997).

\section{Neuropathological Profile of Autosomal- Dominant Mutations}

Autosomal-dominant APP mutations close to the sites of $\beta$ - or $\gamma$-secretase cleavage and flanking the $A \beta$ sequence cause either elevated levels of total $A \beta$ production or a specific increase in A $\beta 42$ peptides, which are more hydrophobic 
J. TCW and A.M. Goate
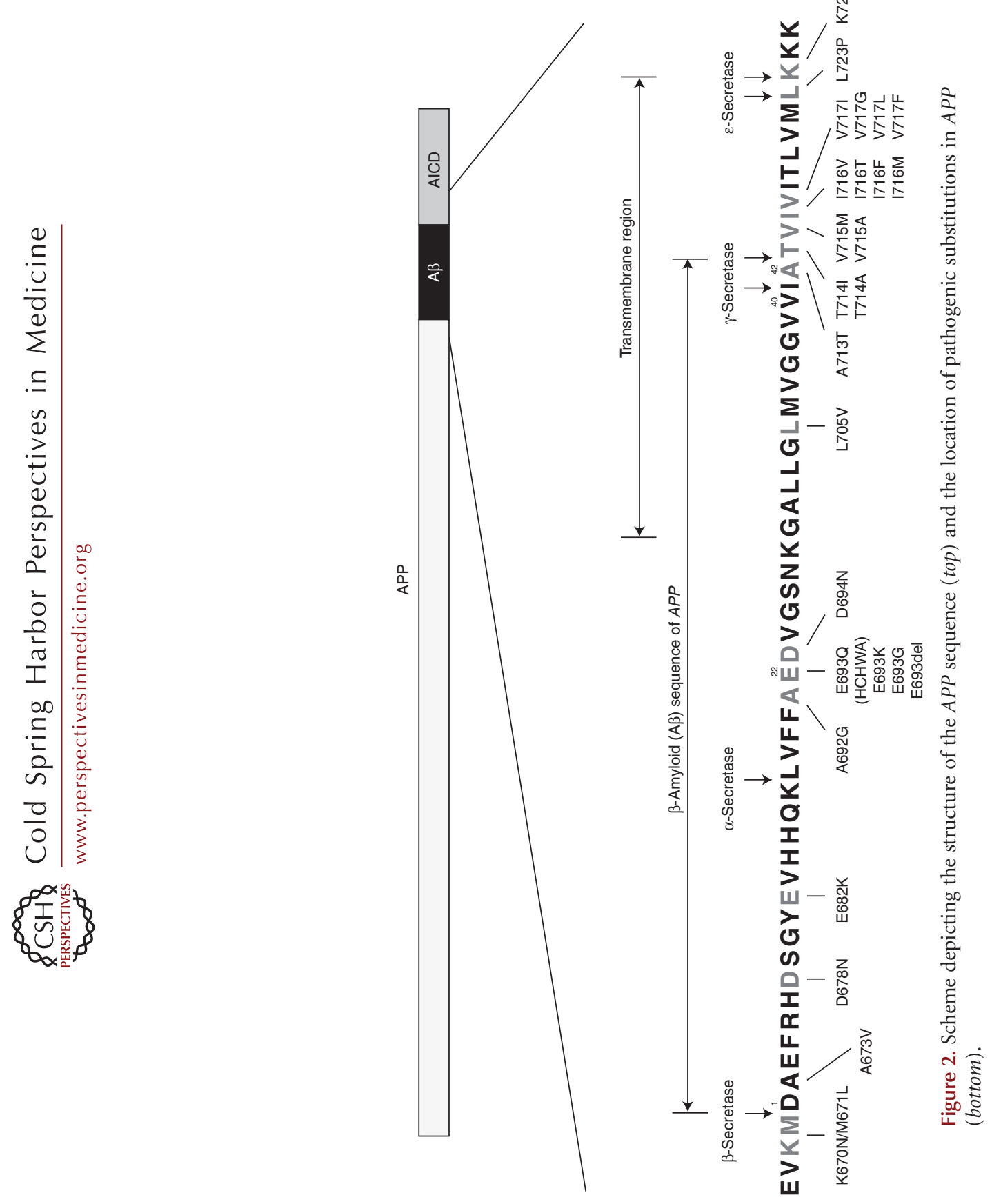
and thus more prone to fibrillogenesis (Suzuki et al. 1994; Tamaoka et al. 1994; Younkin 1994). However, those that alter amino acids within the $\mathrm{A} \beta$ domain facilitate rapid aggregation and fibrillization (Levy et al. 2006). Mutations that cause an increase in $\mathrm{A} \beta 42$ peptides are associated with the classical clinical and neuropathological features of $\mathrm{AD}$, including progressive dementia and senile plaques, neurofibrillary tangles, and neuronal cell loss (Rocchi et al. 2003). In contrast, mutations that are associated with an increase in total $A \beta$ also have prominent $\mathrm{A} \beta$ deposition in cerebral vessels (CAA) and can be clinically associated with cerebral hemorrhages and stroke (Kumar-Singh et al. 2002; Castellani et al. 2004). Although both CAA and senile plaques are observed in the brains of patients with DS, HCHWA-D, and $\mathrm{AD}$, mutations within the $\mathrm{A} \beta$ sequence are predominantly vasculotropic and lack neurofibrillary tangles (Obici et al. 2005; Bugiani et al. 2010). These mutations are also associated with more severe CAA, which is widely distributed throughout the brain (van Duinen et al. 1987; Hendriks et al. 1992; Rossi et al. 2004; RoveletLecrux et al. 2006).

\section{Autosomal-Recessive Mutation and Its Neuropathological Profile \\ The A673V Mutation and Its Effects on $A \beta$ Formation}

A novel APP mutation, an alanine-to-valine substitution at codon 673 (A673V), has been observed as a homozygous recessive mutation in a single Italian pedigree (Fig. 2) (Giaccone et al. 2010). Patients with A673V have earlyonset $\mathrm{AD}$ with behavioral abnormalities at the onset and neurological deficits in later stages. On the basis of the formal neuropsychological assessment, individuals heterozygous for this mutation (aged between 21 and 88 years) had no signs of cognitive decline even at an advanced age.

The A673VAPP variant shifts APP processing toward the amyloidogenic pathway, with increased production of $A \beta$ peptides, and markedly enhances the aggregation and fibrillogenic properties of both $A \beta 40$ and $A \beta 42$ (Giaccone et al. 2010). A 340 is markedly increased in the insoluble fraction and is predominant over $A \beta 42$, suggesting that this mutation strongly enhances the formation of $A \beta 40$ aggregates (Di Fede et al. 2012). However, in vitro studies with synthetic peptides revealed that co-incubation of $\mathrm{A} \beta$ containing the $\mathrm{A} 673 \mathrm{~V}$ variant and WT A $\beta$ species resulted in reduced amyloidogenesis and neurotoxicity of $A \beta$, consistent with the observation that heterozygous carriers do not develop the disease. These opposite effects of the A673V mutation on amyloidogenesis, in the homozygous and heterozygous states, likely account for the autosomal-recessive pattern of inheritance.

\section{Neuropathological Profile of the A673V Mutation in the Homozygous State}

Patients homozygous for the A673V mutation are characterized neuropathologically by the presence of both plaques and tangles but show several distinctive features compared with $\mathrm{AD}$ patients carrying dominant mutations (Giaccone et al. 2010). Patients displayed abundant $\mathrm{A} \beta$ deposits and CAA in all areas of the cerebral cortex, but the $A \beta$ deposits were unusually large (up to $120 \mathrm{~mm}$ in diameter), and the localization of $\mathrm{A} \beta$ deposits was consistently perivascular.

\section{PROTECTIVE RECOMBINANT A673T}

At the same position in the A $\beta$ peptide, APP673, where the recessive mutation was found (Fig. 2), three homozygous carriers of an alanine-tothreonine substitution (A673T) were discovered by whole-genome sequencing in Icelandic samples (Jonsson et al. 2012). None of these homozygous carriers, whose ages ranged from 67 to 88 years, had a history of dementia. This substitution is adjacent to the $\beta$-secretase cleavage site in the APP gene and results in an $\sim 40 \%$ reduction in the formation of $A \beta$ peptides in vitro (Jonsson et al. 2012). This variant was found to be significantly more common in the aged control group than in $\mathrm{AD}$ cases $(0.62 \%$ vs. $0.13 \%$; odds ratio $\left.=5.29 ; P=4.78 \times 10^{-7}\right)$, suggesting that $\mathrm{A} 673 \mathrm{~T}$ reduces the risk for $\mathrm{AD}$. 
A673T is a rare variant, with a reported frequency of $0.2 \%, 0.4 \%, 0.45 \%$, and $0.5 \%$ in the Norwegian, Swedish, Icelandic, and Finnish general populations, respectively, whereas it has not been observed in elderly individuals of Asian descent and is rarely seen in the U.S. population (Jonsson et al. 2012; Kero et al. 2013; Liu et al. 2014).

In vitro studies show that A673T results in a reduced production of sAPP $\beta$ and $\sim 40 \%$ less $A \beta 40$ and $A \beta 42$ compared with WT APP, suggesting that A673Treduces BACE1 ( $\beta$-secretase) cleavage of APP. To further confirm the protective effect of $\mathrm{A} 673 \mathrm{~T}$ against $\mathrm{AD}$, an in vitro BACE1 cleavage assay was performed with a WT synthetic APP peptide and a peptide bearing the A673T substitution. The A673TAPP peptide was processed $\sim 50 \%$ less efficiently than the WT substrate, suggesting that A673T carriers impaired BACE1 cleavage of APP (Jonsson et al. 2012). It has been shown that the A673T substitution decreases the catalytic turnover rate of APP by BACE1, thereby reducing A $\beta$ aggregation (Maloney et al. 2014). Thus, this mutation prevents $A \beta$ aggregation by inhibiting the generation of $A \beta$ peptide from APP. The observation of this rare protective variant that decreases $A \beta$ production and reduces the risk of $\mathrm{AD}$ provides compelling evidence in support of the amyloid hypothesis: mutations that increase $\mathrm{A} \beta$ levels increase the risk for $\mathrm{AD}$, whereas those that decrease $A \beta$ levels reduce the risk for the disease (Fig. 3) (Hardy and Selkoe 2002).

\section{CONCLUDING REMARKS}

The discovery of mutations in $A P P$ that increase or decrease $A \beta$ production and the risk for $A D$ provides strong support for the amyloid cascade hypothesis, which posits that accumulation of $\mathrm{A} \beta$ is the primary effector of $\mathrm{AD}$ pathogenesis (Fig. 3) (Hardy and Selkoe 2002). The amyloid hypothesis proposes that $\mathrm{AD}$ is caused by altered APP expression or APP-mutation-induced $A \beta$ aggregation, following an imbalance between $A \beta$ production and $A \beta$ clearance.

Genetics and genomic studies of $A P P$ have identified 52 pathogenic mutations in $A P P$ that can lead to $A \beta$ deposition in the brain paren-
Amyloid cascade hypothesis

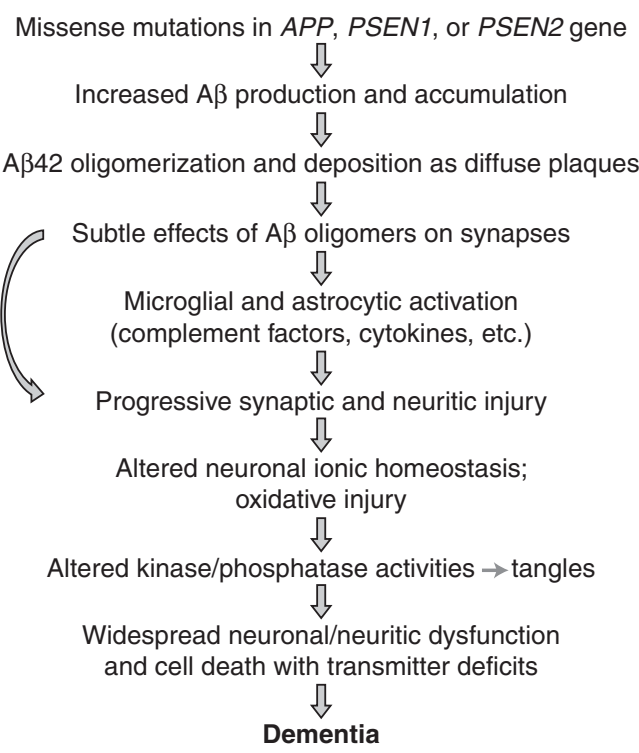

Figure 3. Proposed sequence of pathogenic events leading to Alzheimer's disease.

chyma and in cerebral blood vessels. Studies of these families have conclusively shown that overexpression of the normal $A P P$ sequence (trisomy 21 or APP duplication) or mutations that lead to elevated total $A \beta$, elevated $A \beta 42$, or increased $A \beta$ aggregation lead to dementia and $\mathrm{AD}$ neuropathology. In the presence of elevated total $A \beta$, there is also widespread CAA and hemorrhagic stroke. In contrast, mutations that decrease $A \beta$ levels substantially reduce the risk of developing AD.

Introduction of missense mutations in human APP into transgenic mice has enabled the recapitulation of at least some aspects of $\mathrm{AD}$. These mice show an age-dependent deposition of $A \beta$ in the brain. As is observed in human patients, mice carrying the Swedish mutation (Tg2576) develop diffuse and dense-cored plaques in the brain as well as severe CAA (Hsiao et al. 1996), whereas mice expressing mutations at the $C$ terminus of $A \beta$, such as the V717F mutation, develop plaques but not CAA (Games et al. 1995). These animals do not exhibit neurofibrillary tangles or widespread neuronal loss, but they do exhibit some synapse 
loss. Furthermore, mice unable to generate $A \beta$, such as the $\mathrm{BACE}^{-/-}$mouse, show no neuronal loss and improved cognitive function (Ohno et al. 2004). Together, the human and animal studies strongly support the notion that a therapeutic strategy aimed at reducing $A \beta$ levels by either inhibiting production or increasing clearance could be useful, particularly if applied early enough during the course of disease.

\section{ACKNOWLEDGMENTS}

A.G. and J.TCW are supported by grants from the National Institute on Aging, the JPB Foundation, and the Ronald M. Loeb Center for Alzheimer's Disease.

\section{REFERENCES}

${ }^{*}$ Reference is also in this collection.

Bertram L, Tanzi RE. 2005. The genetic epidemiology of neurodegenerative disease. J Clin Invest 115: 1449-1457.

Bugiani O, Giaccone G, Rossi G, Mangieri M, Capobianco R, Morbin M, Mazzoleni G, Cupidi C, Marcon G, Giovagnoli A, et al. 2010. Hereditary cerebral hemorrhage with amyloidosis associated with the E693K mutation of APP. Arch Neurol 67: 987-995.

Burger PC, Vogel FS. 1973. The development of the pathologic changes of Alzheimer's disease and senile dementia in patients with Down's syndrome. Am J Pathol 73: 457476.

Busciglio J, Gabuzda DH, Matsudaira P, Yankner BA. 1993. Generation of $\beta$-amyloid in the secretory pathway in neuronal and nonneuronal cells. Proc Natl Acad Sci 90: 2092-2096.

Castellani RJ, Smith MA, Perry G, Friedland RP. 2004. Cerebral amyloid angiopathy: Major contributor or decorative response to Alzheimer's disease pathogenesis. Neurobiol Aging 25: 599-602; discussion 603-594.

Citron M, Vigo-Pelfrey C, Teplow DB, Miller C, Schenk D, Johnston J, Winblad B, Venizelos N, Lannfelt L, Selkoe DJ. 1994. Excessive production of amyloid $\beta$-protein by peripheral cells of symptomatic and presymptomatic patients carrying the Swedish familial Alzheimer disease mutation. Proc Natl Acad Sci 91: 11993-11997.

Di Fede G, Catania M, Morbin M, Giaccone G, Moro ML, Ghidoni R, Colombo L, Messa M, Cagnotto A, Romeo M, et al. 2012. Good gene, bad gene: New APP variant may be both. Prog Neurobiol 99: 281-292.

Ellis RJ, Olichney JM, Thal LJ, Mirra SS, Morris JC, Beekly D, Heyman A. 1996. Cerebral amyloid angiopathy in the brains of patients with Alzheimer's disease: The CERAD experience, Part XV. Neurology 46: 1592-1596.

Games D, Adams D, Alessandrini R, Barbour R, Berthelette P, Blackwell C, Carr T, Clemens J, Donaldson T, Gillespie F, et al. 1995. Alzheimer-type neuropathology in trans- genic mice overexpressing V717F $\beta$-amyloid precursor protein. Nature 373: 523-527.

Giaccone G, Morbin M, Moda F, Botta M, Mazzoleni G, Uggetti A, Catania M, Moro ML, Redaelli V, Spagnoli A, et al. 2010. Neuropathology of the recessive A673V APP mutation: Alzheimer disease with distinctive features. Acta Neuropathol 120: 803-812.

Goate A, Chartier-Harlin MC, Mullan M, Brown J, Crawford F, Fidani L, Giuffra L, Haynes A, Irving N, James L, et al. 1991. Segregation of a missense mutation in the amyloid precursor protein gene with familial Alzheimer's disease. Nature 349: 704-706.

Goldgaber D, Lerman MI, McBride OW, Saffiotti U, Gajdusek DC. 1987. Characterization and chromosomal localization of a cDNA encoding brain amyloid of Alzheimer's disease. Science 235: 877-880.

Guyant-Marechal I, Berger E, Laquerriere A, Rovelet-Lecrux A, Viennet G, Frebourg T, Rumbach L, Campion D, Hannequin D. 2008. Intrafamilial diversity of phenotype associated with app duplication. Neurology 71: 1925-1926.

Haass C. 2004. Take five-BACE and the $\gamma$-secretase quartet conduct Alzheimer's amyloid $\beta$-peptide generation. EMBO J 23: 483-488.

Haass C, Hung AY, Selkoe DJ, Teplow DB. 1994. Mutations associated with a locus for familial Alzheimer's disease result in alternative processing of amyloid $\beta$-protein precursor. J Biol Chem 269: 17741-17748.

Hardy J. 1997. Amyloid, the presenilins and Alzheimer's disease. Trends Neurosci 20: 154-159.

Hardy J, Selkoe DJ. 2002. The amyloid hypothesis of Alzheimer's disease: Progress and problems on the road to therapeutics. Science 297: 353-356.

Hattori M, Fujiyama A, Taylor TD, Watanabe H, Yada T, Park HS, Toyoda A, Ishii K, Totoki Y, Choi DK, et al. 2000. The DNA sequence of human chromosome 21. Nature 405: 311-319.

Hendriks L, van Duijn CM, Cras P, Cruts M, Van Hul W, van Harskamp F, Warren A, McInnis MG, Antonarakis SE, Martin JJ, et al. 1992. Presenile dementia and cerebral haemorrhage linked to a mutation at codon 692 of the $\beta$-amyloid precursor protein gene. Nat Genet 1: 218 221.

Henrichsen CN, Chaignat E, Reymond A. 2009. Copy number variants, diseases and gene expression. Hum Mol Genet 18: R1-R8.

Hof PR, Bouras C, Perl DP, Sparks DL, Mehta N, Morrison JH. 1995. Age-related distribution of neuropathologic changes in the cerebral cortex of patients with Down's syndrome. Quantitative regional analysis and comparison with Alzheimer's disease. Arch Neurol 52: 379-391.

Hsiao K, Chapman P, Nilsen S, Eckman C, Harigaya Y, Younkin S, Yang F, Cole G. 1996. Correlative memory deficits, $\mathrm{A} \beta$ elevation, and amyloid plaques in transgenic mice. Science 274: 99-102.

* Johnson DS, Li Y-M, Pettersson M, St George-Hyslop PH. 2016. Structural and chemical biology of presenilin complexes. Cold Spring Harb Perspect Med doi: 10.1101/ cshperspect.a024067.

Jonsson T, Atwal JK, Steinberg S, Snaedal J, Jonsson PV, Bjornsson S, Stefansson H, Sulem P, Gudbjartsson D, Maloney J, et al. 2012. A mutation in APP protects against 
Alzheimer's disease and age-related cognitive decline. Nature 488: 96-99.

Kaminsky YG, Marlatt MW, Smith MA, Kosenko EA. 2010. Subcellular and metabolic examination of amyloid- $\beta$ peptides in Alzheimer disease pathogenesis: Evidence for $A \beta(25-35)$. Exp Neurol 221: 26-37.

Kang J, Lemaire HG, Unterbeck A, Salbaum JM, Masters CL, Grzeschik KH, Multhaup G, Beyreuther K, Muller-Hill B. 1987. The precursor of Alzheimer's disease amyloid A4 protein resembles a cell-surface receptor. Nature 325: 733-736.

Kasuga K, Shimohata T, Nishimura A, Shiga A, Mizuguchi T, Tokunaga J, Ohno T, Miyashita A, Kuwano R, Matsumoto $\mathrm{N}$, et al. 2009. Identification of independent APP locus duplication in Japanese patients with early-onset Alzheimer disease. J Neurol Neurosurg Psychiatry 80: 10501052.

Kero M, Paetau A, Polvikoski T, Tanskanen M, Sulkava R, Jansson L, Myllykangas L, Tienari PJ. 2013. Amyloid precursor protein (APP) A673T mutation in the elderly Finnish population. Neurobiol Aging 34: e1511-e1513.

Korenberg JR, Kawashima H, Pulst SM, Allen L, Magenis E, Epstein CJ. 1990. Down syndrome: Toward a molecular definition of the phenotype. Am J Med Genet 7: 91-97.

Kumar-Singh S, Cras P, Wang R, Kros JM, van Swieten J, Lubke U, Ceuterick C, Serneels S, Vennekens K, Timmermans JP, et al. 2002. Dense-core senile plaques in the Flemish variant of Alzheimer's disease are vasocentric. Am J Pathol 161: 507-520.

Levy E, Carman MD, Fernandez-Madrid IJ, Power MD, Lieberburg I, van Duinen SG, Bots GT, Luyendijk W, Frangione B. 1990. Mutation of the Alzheimer's disease amyloid gene in hereditary cerebral hemorrhage, Dutch type. Science 248: 1124-1126.

Levy E, Prelli F, Frangione B. 2006. Studies on the first described Alzheimer's disease amyloid $\beta$ mutant, the Dutch variant. J Alzheimers Dis 9: 329-339.

Ling Y, Morgan K, Kalsheker N. 2003. Amyloid precursor protein (APP) and the biology of proteolytic processing: Relevance to Alzheimer's disease. Int J Biochem Cell Biol 35: 1505-1535.

Liu YW, He YH, Zhang YX, Cai WW, Yang LQ, Xu LY, Kong QP. 2014. Absence of A673T variant in APP gene indicates an alternative protective mechanism contributing to longevity in Chinese individuals. Neurobiol Aging 35: e911-e932.

Maloney JA, Bainbridge T, Gustafson A, Zhang S, Kyauk R, Steiner P, van der Brug M, Liu Y, Ernst JA, Watts RJ, et al. 2014. Molecular mechanisms of Alzheimer disease protection by the $\mathrm{A} 673 \mathrm{~T}$ allele of amyloid precursor protein. J Biol Chem 289: 30990-31000.

Mann DM, Esiri MM. 1989. The pattern of acquisition of plaques and tangles in the brains of patients under 50 years of age with Down's syndrome. J Neurol Sci 89: 169-179.

Mullan M, Crawford F, Axelman K, Houlden H, Lilius L, Winblad B, Lannfelt L. 1992. A pathogenic mutation for probable Alzheimer's disease in the APP gene at the Nterminus of $\beta$-amyloid. Nat Genet 1: 345-347.

Nilsberth C, Westlind-Danielsson A, Eckman CB, Condron MM, Axelman K, Forsell C, Stenh C, Luthman J, Teplow DB, Younkin SG, et al. 2001. The "Arctic" APP mutation
(E693G) causes Alzheimer's disease by enhanced $\mathrm{A} \beta$ protofibril formation. Nat Neurosci 4: 887-893.

Obici L, Demarchi A, de Rosa G, Bellotti V, Marciano S, Donadei S, Arbustini E, Palladini G, Diegoli M, Genovese E, et al. 2005. A novel A $\beta P P$ mutation exclusively associated with cerebral amyloid angiopathy. Ann Neurol 58: 639-644.

Ohno M, Sametsky EA, Younkin LH, Oakley H, Younkin SG, Citron M, Vassar R, Disterhoft JF. 2004. BACE1 deficiency rescues memory deficits and cholinergic dysfunction in a mouse model of Alzheimer's disease. Neuron 41: 27-33.

Oyama F, Cairns NJ, Shimada H, Oyama R, Titani K, Ihara Y. 1994. Down's syndrome: up-regulation of $\beta$-amyloid protein precursor and tau mRNAs and their defective coordination. J Neurochem 62: 1062-1066.

Patterson D. 2009. Molecular genetic analysis of Down syndrome. Hum Genet 126: 195-214.

Pfeifer LA, White LR, Ross GW, Petrovitch H, Launer LJ. 2002. Cerebral amyloid angiopathy and cognitive function: The HAAS autopsy study. Neurology 58: 1629-1634.

Prasher VP, Farrer MJ, Kessling AM, Fisher EM, West RJ, Barber PC, Butler AC. 1998. Molecular mapping of Alzheimer-type dementia in Down's syndrome. Ann Neurol 43: $380-383$.

* Prusiner SB. 2016. A $\beta$ prions and pathobiology of Alzheimer's disease. Cold Spring Harb Perspect Med doi: 10.1101/cshperspect.a030676.

Rahmani Z, Blouin JL, Creau-Goldberg N, Watkins PC, Mattei JF, Poissonnier M, Prieur M, Chettouh Z, Nicole A, Aurias A, et al. 1989. Critical role of the D21S55 region on chromosome 21 in the pathogenesis of Down syndrome. Proc Natl Acad Sci 86: 5958-5962.

Rocchi A, Pellegrini S, Siciliano G, Murri L. 2003. Causative and susceptibility genes for Alzheimer's disease: A review. Brain Res Bull 61: 1-24.

Rossi G, Giaccone G, Maletta R, Morbin M, Capobianco R, Mangieri M, Giovagnoli AR, Bizzi A, Tomaino C, Perri M, et al. 2004. A family with Alzheimer disease and strokes associated with A713T mutation of the APP gene. Neurology 63: 910-912.

Rovelet-Lecrux A, Hannequin D, Raux G, Le Meur N, Laquerriere A, Vital A, Dumanchin C, Feuillette S, Brice A, Vercelletto M, et al. 2006. APP locus duplication causes autosomal dominant early-onset Alzheimer disease with cerebral amyloid angiopathy. Nat Genet 38: 24-26.

Rumble B, Retallack R, Hilbich C, Simms G, Multhaup G, Martins R, Hockey A, Montgomery P, Beyreuther K, Masters CL. 1989. Amyloid A4 protein and its precursor in Down's syndrome and Alzheimer's disease. N Engl J Med 320: $1446-1452$.

Sadowski M, Wisniewski HM, Tarnawski M, Kozlowski PB, Lach B, Wegiel J. 1999. Entorhinal cortex of aged subjects with Down's syndrome shows severe neuronal loss caused by neurofibrillary pathology. Acta Neuropathol 97: 156164.

Salehi A, Delcroix JD, Belichenko PV, Zhan K, Wu C, Valletta JS, Takimoto-Kimura R, Kleschevnikov AM, Sambamurti K, Chung PP, et al. 2006. Increased App expression in a mouse model of Down's syndrome disrupts NGF transport and causes cholinergic neuron degeneration. Neuron 51: 29-42. 
APP Genetics

Sandbrink R, Masters CL, Beyreuther K. 1996. APP gene family. Alternative splicing generates functionally related isoforms. Ann NY Acad Sci 777: 281-287.

Sleegers K, Brouwers N, Gijselinck I, Theuns J, Goossens D, Wauters J, Del-Favero J, Cruts M, van Duijn CM, Van Broeckhoven C. 2006. APP duplication is sufficient to cause early onset Alzheimer's dementia with cerebral amyloid angiopathy. Brain 129: 2977-2983.

Suzuki N, Cheung TT, Cai XD, Odaka A, Otvos L Jr, Eckman C, Golde TE, Younkin SG. 1994. An increased percentage of long amyloid $\beta$ protein secreted by familial amyloid $\beta$ protein precursor $(\beta$ APP717) mutants. Science 264: 1336-1340.

Tamaoka A, Odaka A, Ishibashi Y, Usami M, Sahara N, Suzuki N, Nukina N, Mizusawa H, Shoji S, Kanazawa I, et al. 1994. APP717 missense mutation affects the ratio of amyloid $\beta$ protein species $(A \beta 1-42 / 43$ and $A \beta 1-40)$ in familial Alzheimer's disease brain. J Biol Chem 269: 32721-32724.

Tanzi RE, Gusella JF, Watkins PC, Bruns GA, St GeorgeHyslop P, Van Keuren ML, Patterson D, Pagan S, Kurnit DM, Neve RL. 1987. Amyloid $\beta$ protein gene: cDNA, mRNA distribution, and genetic linkage near the Alzheimer locus. Science 235: 880-884.

Teller JK, Russo C, DeBusk LM, Angelini G, Zaccheo D, Dagna-Bricarelli F, Scartezzini P, Bertolini S, Mann DM, Tabaton M, et al. 1996. Presence of soluble amyloid $\beta$-peptide precedes amyloid plaque formation in Down's syndrome. Nat Med 2: 93-95.

Thonberg H, Fallstrom M, Bjorkstrom J, Schoumans J, Nennesmo I, Graff C. 2011. Mutation screening of patients with Alzheimer disease identifies APP locus duplication in a Swedish patient. BMC Res Notes 4: 476.

* Tycko R. 2016. Molecular structure of aggregated amyloid$\beta$ : Insights from solid-state nuclear magnetic resonance. Cold Spring Harb Perspect Med 8: a024083. van Duinen SG, Castano EM, Prelli F, Bots GT, Luyendijk W, Frangione B. 1987. Hereditary cerebral hemorrhage with amyloidosis in patients of Dutch origin is related to Alzheimer disease. Proc Natl Acad Sci 84: 5991-5994.

Wiltfang J, Esselmann H, Bibl M, Smirnov A, Otto M, Paul S, Schmidt B, Klafki HW, Maler M, Dyrks T, et al. 2002. Highly conserved and disease-specific patterns of carboxyterminally truncated $A \beta$ peptides $1-37 / 38 / 39$ in addition to 1-40/42 in Alzheimer's disease and in patients with chronic neuroinflammation. J Neurochem 81: 481-496.

Wisniewski KE, Wisniewski HM, Wen GY. 1985. Occurrence of neuropathological changes and dementia of Alzheimer's disease in Down's syndrome. Ann Neurol 17: 278-282.

Wisniewski T, Ghiso J, Frangione B. 1991. Peptides homologous to the amyloid protein of Alzheimer's disease containing a glutamine for glutamic acid substitution have accelerated amyloid fibril formation. Biochem Biophys Res Commun 180: 1528.

Wolfe MS, Guenette SY. 2007. APP at a glance. J Cell Sci 120: 3157-3161.

Yoshikai S, Sasaki H, Doh-ura K, Furuya H, Sakaki Y. 1990. Genomic organization of the human amyloid $\beta$-protein precursor gene. Gene 87: 257-263.

Younkin SG. 1994. The amyloid $\beta$ protein precursor mutations linked to familial Alzheimer's disease alter processing in a way that fosters amyloid deposition. Tohoku J Exp Med 174: 217-223.

Zarrei M, MacDonald JR, Merico D, Scherer SW. 2015. A copy number variation map of the human genome. Nat Rev Genet 16: 172-183.

Zigman WB. 2013. Atypical aging in Down syndrome. Dev Disabil Res Rev 18: 51-67. 


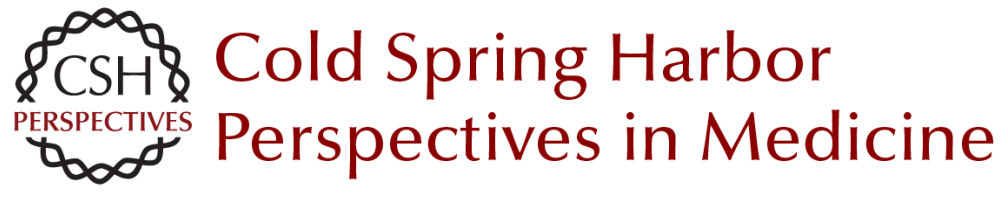

\section{Genetics of $\beta$-Amyloid Precursor Protein in Alzheimer's Disease}

Julia TCW and Alison M. Goate

Cold Spring Harb Perspect Med 2017; doi: 10.1101/cshperspect.a024539 originally published online December 21, 2016

\section{Subject Collection Prion Diseases}

TDP-43 Prions

Takashi Nonaka and Masato Hasegawa

$\alpha$-Synuclein: Multiple System Atrophy Prions Amanda L. Woerman, Joel C. Watts, Atsushi Aoyagi, et al.

Genetics of Synucleinopathies Robert L. Nussbaum

$\beta$-Amyloid Prions and the Pathobiology of

Alzheimer's Disease Joel C. Watts and Stanley B. Prusiner

Disease Mechanisms of C9ORF72 Repeat Expansions

Tania F. Gendron and Leonard Petrucelli

Chronic Traumatic Encephalopathy: Is Latency in

Symptom Onset Explained by Tau Propagation? Joshua Kriegel, Zachary Papadopoulos and Ann C. McKee

Noncerebral Amyloidoses: Aspects on Seeding, Cross-Seeding, and Transmission Gunilla T. Westermark, Marcus Fändrich, Katarzyna Lundmark, et al.

Structural and Chemical Biology of Presenilin Complexes

Douglas S. Johnson, Yue-Ming Li, Martin

Pettersson, et al.
Cell Biology and Pathophysiology of $\alpha$-Synuclein Jacqueline Burré, Manu Sharma and Thomas C. Südhof

Molecular Mechanisms of Chronic Wasting

Disease Prion Propagation Julie A. Moreno and Glenn C. Telling

Genetics of Amyotrophic Lateral Sclerosis Mehdi Ghasemi and Robert H. Brown, Jr.

The Genetics of C9orf72 Expansions Ilse Gijselinck, Marc Cruts and Christine Van Broeckhoven

Prion-Like Characteristics of Polyglutamine-Containing Proteins Margaret M.P. Pearce and Ron R. Kopito

Therapeutic Strategies for Restoring Tau Homeostasis

Zapporah T. Young, Sue Ann Mok and Jason E. Gestwicki

Fused in Sarcoma Neuropathology in Neurodegenerative Disease Ian R.A. Mackenzie and Manuela Neumann

Experimental Models of Inherited PrP Prion Diseases Joel C. Watts and Stanley B. Prusiner

For additional articles in this collection, see http://perspectivesinmedicine.cshlp.org/cgi/collection/ 